\title{
greenhouse gas emissions
}

World Wide Fund for Nature.

"Now that Kohl has put climate protection high on the political agenda it will be hard for the finance ministry to block the wishes of the environment ministry, as has happened in the past," says Singer. Germany will now have to look seriously at measures which will reduce emissions in the west of the country, he says.

Intense and prolonged negotiations followed Kohl's speech, continuing until the small hours on 7 April. The resulting agreement, known as the Berlin mandate, states that the present commitment under the Rio climate convention is inadequate, and establishes a procedure that will set voluntary targets for reduction of all greenhouse gases after the year 2000 .

A working group will be set up to design the protocol for approval in 1997. The group will consider quantified targets for limiting or reducing emissions within a time-frame that has still to be decided. The agreement mentions the dates 2005, 2010 and 2020, but makes no specific recommendation.

In addition to the Berlin mandate, delegates agreed to launch a pilot phase for joint implementation projects. But, initially, the investing country will not be able to claim credit for reduced emissions in

the full Conference of Parties. One, the Subsidiary Body for Scientific and Technical Advice (SBSTA), will convey scientific information to the COP.

The Subsidiary Body for Implementation (SBI), will advise the COP on national implementation of the convention. Both subsidiary bodies will be open to delegates - who need not be technical experts - nominated by each of the 128 signatory states, and will hold their first sessions in October.

The SBSTA will be chaired by Tibor Farago, head of environmental policy in Hungary's Environment Ministry, and will be able to seek advice from any qualified scientific or technological advisory body though the only body explicitly mentioned in this regard, is the IPCC. Some see a danger in this. "SBSTA will be composed of delegates and not scientists," says Arjet Stevens from Greenpeace International. "There is a risk that it could choose to take advice from bodies that are not genuinely independent."

Farago, a geophysicist who has worked as a climatologist, concedes that governments cannot be forced to delegate technically qualified people onto the SBSTA committee, but he hopes that the governments "will be motivated to do so". He describes IPCC as "one of the most important bodies" with which he will be cooperating.

Greenpeace and other environmental the pilot phase. The situation will be reviewed in 1999.

Another decision agreed by the delegates was to set up subsidiary bodies to assess scientific data on global warming and to review the way in which countries are meeting their commitments (see below). They also decided to locate the convention's permanent secretariat in Bonn.

Germany's former capital, which will have plenty of office space when the government moves to Berlin in 1997, offered rentfree premises and support of up to DM3.5 million (US\$2.5 million) a year. The secretariat will receive from the United Nations further support of just under US\$9 million over the next two years, during which time it will build up a staff of 50 .

Matthew Spencer, a spokesman for the environmentalist group Greenpeace, said after the meeting that many such groups regretted that the Berlin conference did not agree a target of a 20 per cent cut in greenhouse gas emissions, as had been demanded by many developing countries.

"But governments have eighteen months to find ways of doing this," he says. "So we are still optimistic, and we believe that there has been a tentative step forward."

Alison Abbott

groups would have preferred IPCC to remain the only official scientific advisory body. But IPCC says it does not feel threatened. "We are very happy with the proposal," says Bolin, who feels it appropriate that IPCC itself is not too closely tied to COP.

Scientists who have helped prepare the IPCC reports say they are pleased that its future as a key advisory body is now secure. "It is the only body that can do a good job," says Klaus Hassalmann from the Max Planck Institute for Meteorology in Hamburg. "It reflects the [main] view of the whole scientific community, and also conveys the degree of variability around that average view."

Bruce Callander of the United Kingdom's Meteorological Office, head of the technical support unit for IPCC's first working group, says that if the COP had decided not to use the IPCC, it would have had to reinvent the panel under a different name. "It has the goodwill of the best scientists," he says.

But both Hassalmann and Callander agree that this goodwill needs to be nurtured, and that scientists could rebel if asked to write a third report too soon. They point out that nothing is likely to happen in the near future to substantially change the IPCC's conclusions - and that the most important task for politicians now is to implement its recommendations.

A.A.

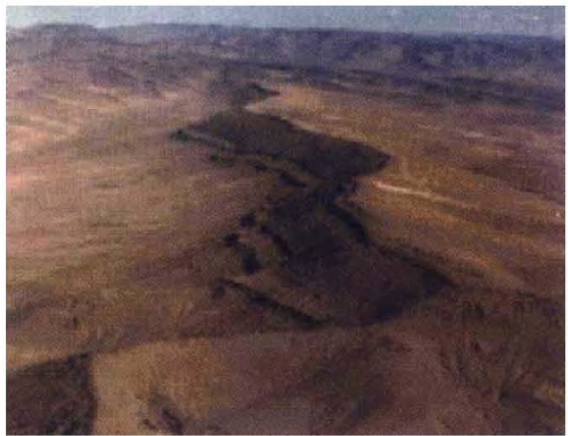

Yucca Mountain: long-term danger?

\section{Academy may probe waste 'explosion' risk}

Washington. The US National Academy of Sciences may be asked to assess controversial claims by two physicists at the Los Alamos National Laboratory that nuclear waste stored in a planned underground repository at Yucca Mountain, Nevada, could spontaneously explode.

The authors of a paper suggesting this possibility - Charles Bowman and Francesco Venneri - are both particle physicists and leading proponents of the use of particle accelerators for disposing of nuclear waste by transmutating its fissile isotopes.

Their paper says that plutonium and other fissile material stored in barrels underground would eventually leak, and that, mixed with rock that would act as a moderator, they could reach criticality and explode (see Nature 374, 204;1995).

Hazel O'Leary, the energy secretary, told the Senate Armed Services Committee last week that the academy had offered to assess the theory. Asked for her own assessment, O'Leary said she gave it "the credibility I would give to anyone who didn't have the assignment and, quite frankly, had another interest".

But Bowman and Venneri were defended by Richard Bryan (Democrat, Nevada), a strong opponent of plans to store civil nuclear waste under Yucca Mountain. "They are respected physicists, not people who got their degrees at some degree mill," Bryan said.

Bryan compared the two physicists to Galileo, who, he pointed out, had been branded a heretic in his day. He also alleged that Bowman had been muzzled by the management at Los Alamos - a charge that O'Leary promised to investigate.

Bowman and Venneri are now searching for a peer-reviewed journal prepared to publish their work. Jerry Saltzman, an official at the energy department's office of nuclear waste management, says that the department is waiting to see whether external peer reviewers support publication of the work, which was summarily dismissed by internal reviewers at Los Alamos itself. If so, the department plans to ask the academy to resolve the dispute.

Colin Macilwain 